\title{
In vitro Plantlets Regeneration from Nodal Segments of Murici (Byrsonima gardneriana)
}

\author{
Francisca S. Sá ${ }^{1}$, Jorge M. P. Porto ${ }^{1}$, Alone L. Brito ${ }^{1}$, José R. F. Santana ${ }^{1}$, Rafaeli A. V. Souza ${ }^{1}$ \\ $\&$ Francyane T. Braga ${ }^{1}$ \\ ${ }^{1}$ Departamento de Educação, Universidade do Estado da Bahia, Paulo Afonso, Bahia, Brazil \\ ${ }^{2}$ Departamento de Ciências Biológica, Universidade Estadual de Feira de Santana, Feira de Santana, Bahia, Brazil \\ Correspondence: Francyane T. Braga, Departamento de Educação, Universidade do Estado da Bahia, Rua da \\ Gangorra, 503, Paulo Afonso, BA 48608-240, Brazil. Tel: 55-(75)-99210-3432. E-mail: ftbraga@yahoo.com.br
}

Received: December 14, 2017 Accepted: February 1, $2018 \quad$ Online Published: March 15, 2018

doi:10.5539/jas.v10n4p402 URL: https://doi.org/10.5539/jas.v10n4p402

\begin{abstract}
This study aimed to develop efficient protocols for the in vitro micropropagation of Byrsonima gardneriana. Nodal segments were obtained from seedlings germinated in vitro with 60 days of life. These were inoculated in $\mathrm{MS} / 2$ supplemented with $87.64 \mu \mathrm{M}$ of sucrose and solidified with $0.7 \%$ of agar, supplemented with different concentrations of cytokinin 6-benzylaminopurine $(0.0 ; 2.0 ; 4.0$ and $8.0 \mu \mathrm{M})$ associated with different concentrations of auxin, indole acetic acid $(0.0 ; 0.5$ and $1.0 \mu \mathrm{M})$ and naphthaleneacetic acid $(0.0 ; 0.5$ and 1.0 $\mu \mathrm{M})$. The sprouting were individualized and transferred to MS/2 cultures with different concentrations of indole butyric acid $(0.0 ; 1.0 ; 2.0$ and $3.0 \mu \mathrm{M})$, and presence and absence of activated charcoal $\left(1.0 \mathrm{~g} \mathrm{~L}^{-1}\right)$. The use of concentrations from 2.0 to $4.0 \mu \mathrm{M}$ 6-benzylaminopurine was efficient in the multiplication of B. gardneriana, given that, using concentrations above these, a decrease in this efficiency occurs. The use of auxin interfered negatively with the results. In vitro rooting occurs even in medium free of auxin. The activated charcoal was insufficient for rooting. The use of growth regulators 6-benzylaminopurine and indole butyric acid are efficient in micropropagation of B. gardneriana, however, further studies should be performed to optimize this protocol.
\end{abstract}

Keywords: auxins, Caatinga biome, cytokinins, multiplication, rooting

\section{Introduction}

Byrsonima gardneriana A. Juss. (Malpighiaceae) is native and endemic of Brazil (Seixas, Silva, Morais, \& Santos, 2011). It is known in some regions of Northeastern Brazil, mainly in the Caatinga biome, as murici and murici pitanga. The fresh fruits are highly appreciated, being consumed in natura, as well as juices, popsicles, liquors, jellies, sweets, preserves and in the form of flour. Local populations live off extractive activities and, this species is one of their sources of income when commercialized in free markets (Donadio, Môro, \& Servidone, 2002). In addition to the fruit, the remaining parts of the plant are widely used for therapeutic means, having some of the properties proven in laboratory (Sannomiya et al., 2005).

Despite the significant potential of the species, there are no reports in literature regarding propagation studies. In this context, it is necessary to design strategies to ensure the sustainable multiplication, conservation and use of this species. Tissue culture techniques, especially micropropagation, represents an important alternative for the production of seedlings and the conservation of this genetic resource, allowing us to obtain plants with identical genetic characteristics in large scale and short period of time. In the in vitro propagation, an explant is isolated and cultivated under aseptic conditions, in an artificial medium generally supplemented with plant regulators. The basic principal of tissue culture is cell totipotentiality, i.e., any cell in the plant organism contains all genetic information necessary to regenerate a complete plant (Grattapaglia \& Machado, 1998).

For obtaining efficient protocols for in vitro morphogenesis, it is necessary to adjust the existing protocols for each species, due to the variations in the responses obtained. In this dedifferentiation and re-differentiation induction process, responsible for the formation of tissues and organs, the use of plant regulators capable of stimulating the formation of the aerial part and of the roots are necessary. In this aspect, it is almost a rule that the auxin/cytokinin balance, favorable to the first, stimulate rooting; the counter balance favors the formation of the aerial part (Torres, Caldas, \& Buso, 1998). 
Thus, considering the importance of the species and the absence of propagation studies, the objective of the present study was to establish a micropropagation protocol for this species, by means of direct organogenesis.

\section{Materials and Methods}

Murici ripe fruits and inflorescences were sampled from natural population located at the environmental protection area Serra Branca/Raso da Catarina, Jeremoabo, Bahia, Brazil $\left(10^{\circ} 00^{\prime} 49.1^{\prime \prime} \mathrm{S}\right.$ and $\left.38^{\circ} 22^{\prime} 52.4^{\prime \prime} \mathrm{W}\right)$. The botanic identification was performed at the herbarium of the University of State of Bahia, where the exsiccates are deposited under registry number 28450 .

After the sampling, the fruits underwent processing, with the removal of the pulp and washing in current water during 10 minutes. After drying, the fruits were stored in paper bags, at $10{ }^{\circ} \mathrm{C}$.

The murici fruits had their endocarps manually opened with the aid of a vise bench for the removal of the seeds. Subsequently, the seeds were disinfected in laminar flow chamber and immersed in alcohol $70 \%$ for 30 seconds, followed by immersion in sodium hypochloride at $2.5 \%$ added of a drop of neutral detergent for 10 minutes, and washed four times in autoclaved distilled water. Posteriorly, the culture medium used for the seed germination and all trials was MS/2 (Murashige \& Skoog, 1962) supplemented with $87.64 \mathrm{mM}$ of sucrose, and solidified with $0.7 \%$ of agar. The $\mathrm{pH}$ of the culture medium was adjusted to $5.8 \pm 0.1$ (using $\mathrm{NaOH}$ or $\mathrm{HCl} 0.1 \mathrm{~N}$ ) before autoclaving. The culture medium was distributed into test tubes $(25 \times 150 \mathrm{~mm})$ sealed with plastic cover and sterilized by autoclaving for 15 minutes at a temperature of $120^{\circ} \mathrm{C}$ and pressure of $1 \mathrm{~atm}$. The inoculations were performed in laminar flow chamber for maintaining the aseptic conditions, and the recipients were closed with polyvinyl chloride (PVC) film. The cultures were maintained in growth room with temperature of $25 \pm 3{ }^{\circ} \mathrm{C}$, photoperiod of 16 hours, relative humidity of $60 \%$ and active photosynthetic radiation of $40 \mu \mathrm{mol} \mathrm{m} \mathrm{m}^{-2} \mathrm{~s}^{-1}$.

For in vitro multiplication, we used plantlets derived from in vitro germination of approximately 60 days. Explants (nodal segments) with length of $0.5 \mathrm{~cm}$, derived from plantlets germinated in vitro, were inoculated in test tubes containing $10 \mathrm{~mL}$ of culture medium added with different concentrations of 6-benzylaminopurine (0.0, 2.0, 4.0 and $8.0 \mu \mathrm{M})$, associated to different concentrations of indole acetic acid $(0.0,0.5$ and $1.0 \mu \mathrm{M})$ or different concentrations of naphthaleneacetic acid $(0.0,0.5$ and $1.0 \mu \mathrm{M})$.

The experimental design was completely randomized in a $4 \times 3$ factorial scheme, in experiments, with five replicates, and each replicate comprised of four test tubes containing one explant. For all multiplication experiments, after 45 days, we evaluated: percentage of shoots, length of the shoot, number of shoots and leaves per shoot.

For the induction of the roots, shoots presenting the best results from the previous experiment were individualized and transferred to test tubes containing $10 \mathrm{~mL}$ of $\mathrm{MS} / 2$ culture medium, supplemented with different concentrations of indolbutiric acid $(0.0,1.0,2.0$ and $3.0 \mu \mathrm{M})$, in the presence of $1.0 \mathrm{~g} \mathrm{~L}^{-1}$ and in the absence of activated charcoal. The experimental design was completely randomized in a $4 \times 2$ factorial scheme (four concentrations of auxin indolbutiric acid $\times$ two concentrations of activated charcoal), totalizing eight treatments. Each treatment constituted of five replicates, each comprised of four tubes containing one shoot. After 45 days, we evaluated: survival percentage of the shoots; number of roots; length of the longest root; rooting percentage.

The data were statistically evaluated by means of analysis of variance, comparing the means using the Scott-Knott test (at $5 \%$ of significance), when qualitative, and compared by polynomial regression, when quantitative. The data were analyzed with the aid of the SISVAR 4.3 program (Ferreira, 2011).

\section{Results and Discussion}

To shooting induction in nodal segments using BAP and IAA, we verified, with the analysis of variance, significant effect $(p \leq 0.05)$ just for concentration of plant regulator IAA (Figure 1), and the average percentage of shoot induction was $60 \%$. 

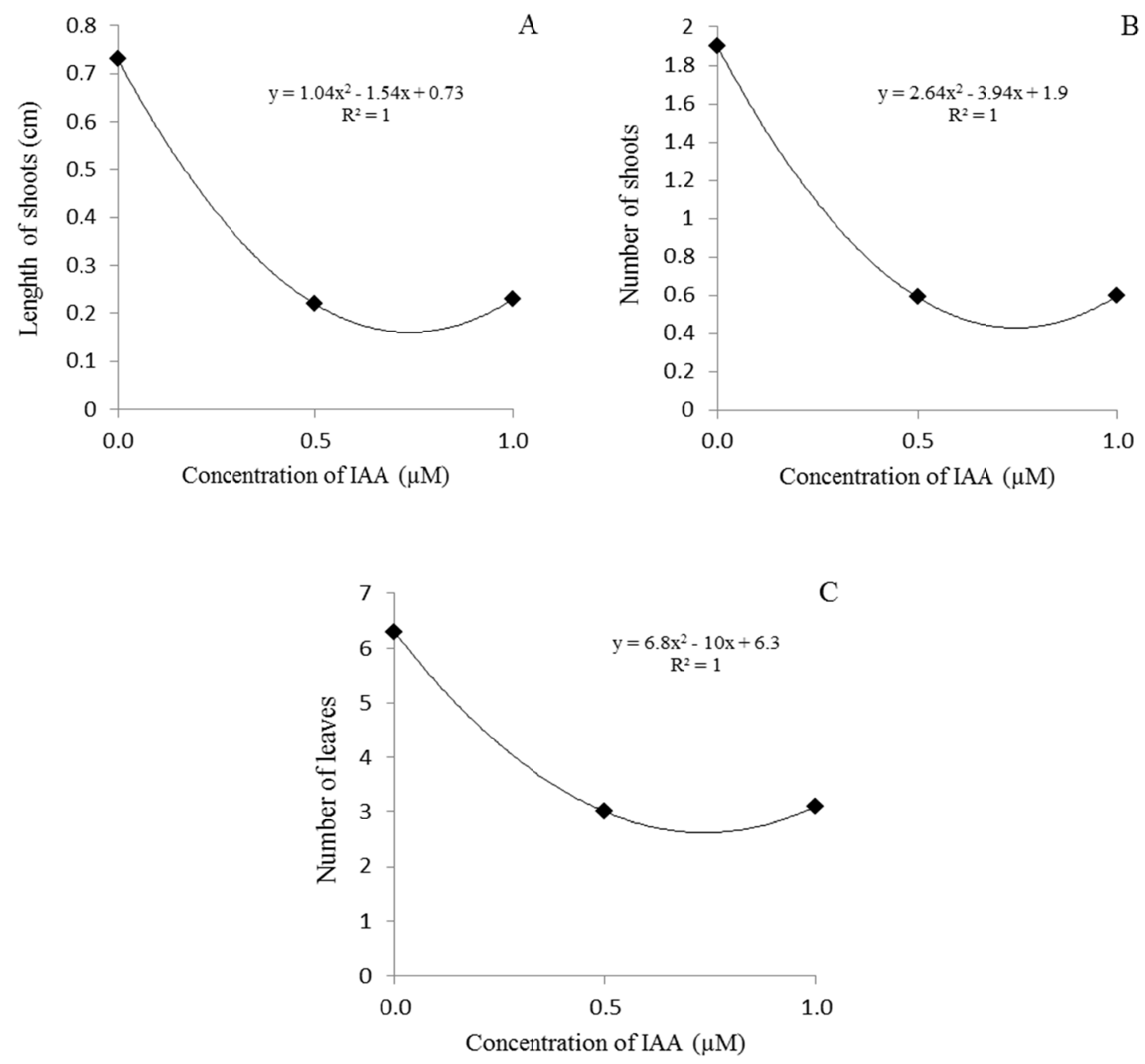

Figure 1. Length of shoots (A), number of shoots (B), and number of Byrsonima gardneriana A. Juss leaves (C) submitted to different concentration of IAA

For variables length of the shoot (Figure 1A), number of shoots (Figure 1B), and number of leaves (Figure 1C), the regression analysis demonstrated a quadratic behavior, in which the absence of auxin IAA verified higher means for all analyzed variables. However, inasmuch as the concentration of IAA increased, we verified a decrease in these variables.

With the results obtained in this experiment, we verified that the use of auxin IAA until the concentration of 1.0 $\mu \mathrm{M}$ showed effect negative in the in vitro multiplication of $B$. gardneriana. It is possible infer that the used concentrations were not capable of promoting an endogenous hormonal balance favorable for the multiplication of the specie in question. Similar results were observed by Noleto and Silveira (2004) in the multiplication of Copaifera langsdorffii Desf., who verified that the addition of IAA to the culture medium in the tested conditions exerted no influence over the evaluated parameters for this species. For the tested concentrations of BAP, we verified no significant effect for the variables analyzed, given that the results did not differ from the culture medium exempt of regulator, presenting general mean of $0.39,1.03$ and $4.08 \mathrm{~cm}$ for length of shoot, number of shoots and number of leaves, respectively. Martendal et al. (2014), when testing high concentrations of BAP $(11.1,22.2$ and $44.4 \mu \mathrm{M})$ in the multiplication of Byrsonima cydoniifolia A. Juss from nodal segments, verified that there was no significance in the tested concentrations for the number of shoots and length of the shoot. However, for the number of leaves, the use of $22.2 \mu \mathrm{M}$ presented better response (4.94). In multiplication studies with nodal segments Handroanthus chrysotrichus (Mart. ex DC.) Mattos (Pereira, Navroski, \& Reiniger, 2015), the addition of BAP showed no considerable benefit, given that, with the increase in the concentration of cytokinin decreased the formation of shoots, in addition to considerably increasing the formation of calluses. 
Cytokinins are indispensable for breaking apical dormancy and inducing the proliferation of auxiliary gems. The type of cytokinin and its concentration are the factors that most influence the success of in vitro multiplication (Grattapaglia \& Machado, 1998). According to Furtado, Carvalho, Castro, and Silva (2007), the morphologic response is strongly influenced by the genotype. Thus, it is fundamental that the protocols be adapted to each species. For obtaining the best result of de B. gardneriana multiplication, it is necessary to test other cytokinins, or even other concentrations associated the concentration of other auxins, thus establishing an internal hormonal balance, with the intent of optimizing the multiplication process.

To shooting induction in nodal segments using BAP and NAA, the analysis of variance showed a significant effect $(p \leq 0.05)$ for the BAP plant regulator concentration variation factor for all analyzed variables (Figure 2), except for percentage of shoots, which presented $100 \%$ of induction for all treatments. While observing a significant effect for the interaction of BAP concentrations to the concentrations of NAA only for the variable length of the shoot (Figure 2A), as well as a significant effect for the NAA plant regulator concentration variation factor for the variable number of leaves (Figure 2D).
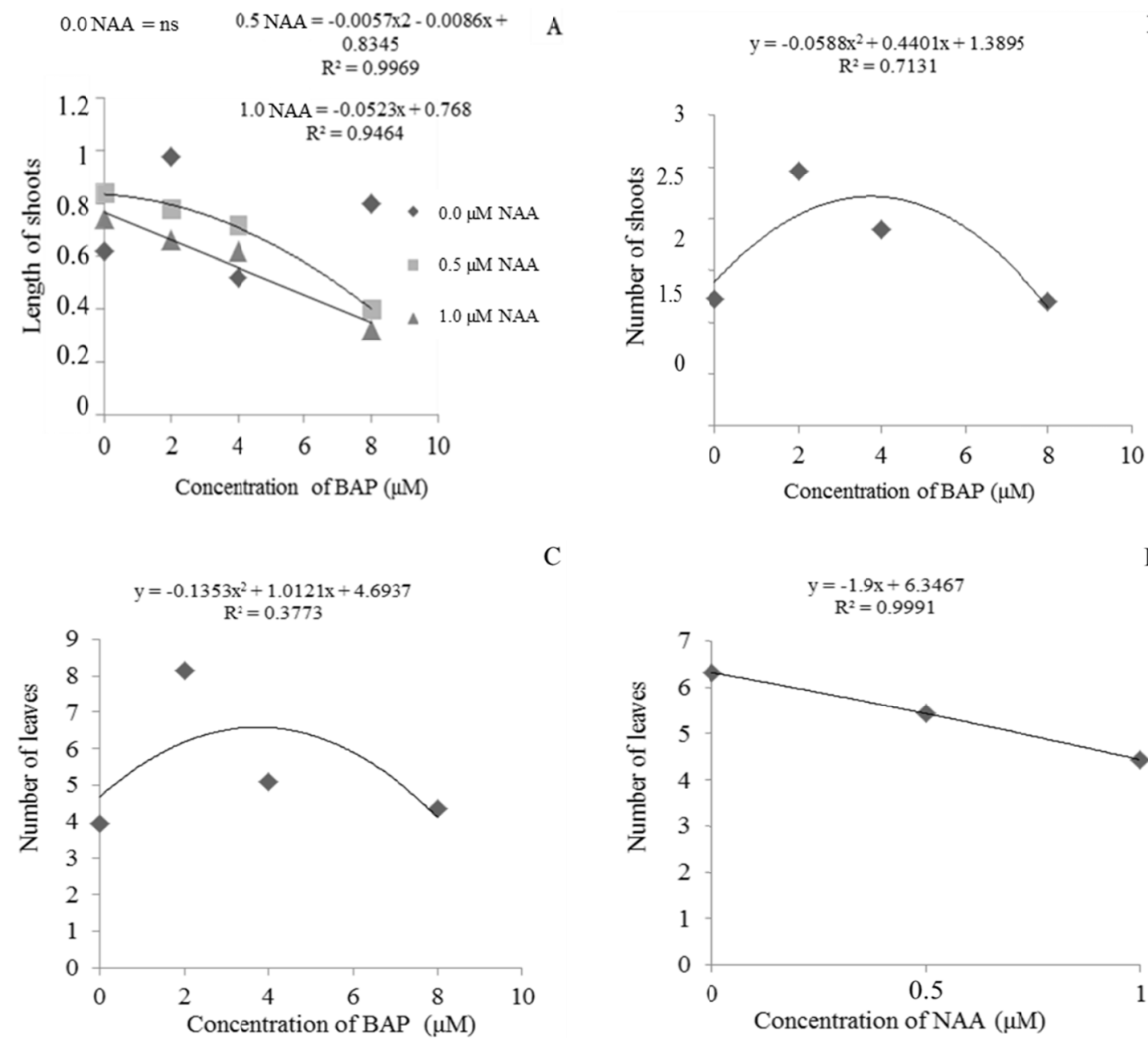

$\mathrm{C}$

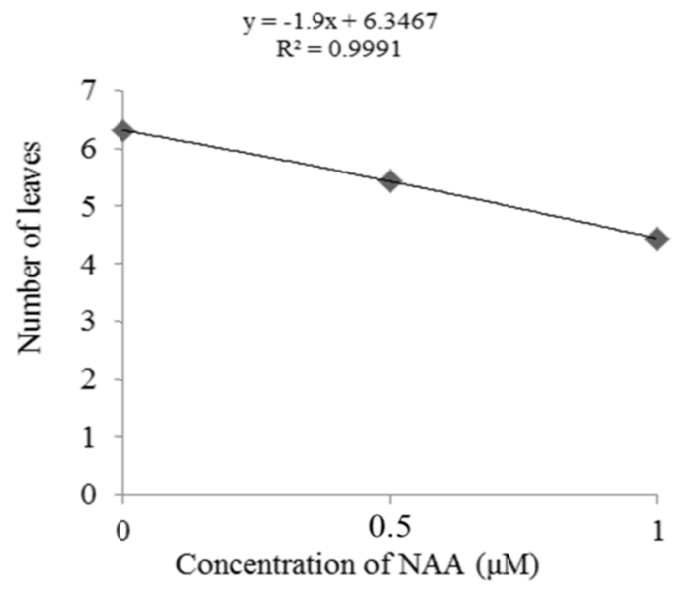

Figure 2. Length of shoots (BAP $\times$ NAA) (A); number of shoots (B); number of leaves (BAP) (C); and number of leaves (NAA) (D) from the nodal segment of Byrsonima gardneriana A. Juss

In the interaction of the different concentrations of BAP combined to different concentrations of NAA for the variable length of the shoot, in the absence of auxin NAA, there was no representative mathematical adjustment. For the concentration of $0.5 \mu \mathrm{M}$ of NAA, the regression analysis indicated an ascending quadratic model, in which elevated supplements of BAP tend to disfavor the increase of the length of the shoot. For the concentration of $1.0 \mu \mathrm{M}$ of NAA, the regression analysis pointed to a decreasing linear model, with the higher mean in length of the shoot found in the absence of BAP, corroborating Kang, Osburn, Kopsell, Tuskan, and 
Cheng (2009) that also registered greater length of the shoots $(22 \mathrm{~mm})$ of Populus trichocarpa Torr. and A. Gray, in medium exempt of plant growth regulators. It is noted by many authors that the increase in the concentration of cytokinins in the medium can cause the reduction in the length of the shoots (Costa, Nepomuceno, \& Santana, 2010), given its performance in breaking the apical dormancy caused by the endogenous auxins of the explants.

For the variable number of shoots (Figure 2B), the regression analysis indicated an ascendant quadratic model for the concentrations of BAP. The response curve obtained for the number of shoots in the presence of BAP allowed us to verify that the use of BAP in concentrations from 2 to $4 \mu \mathrm{M}$ reached the maximum number of shoots per explant. However, in higher concentration of BAP, these numbers decreased. With these results, we can infer that, for the multiplication of $B$. gardneriana, it is unnecessary to use elevated concentrations of the BAP cytokinin. A similar result was reported by Aragão, Aloufa, and Costa (2011) when testing different concentrations of the BAP cytokinin, verifying that the concentration of $2.5 \mu \mathrm{M}$ was the most indicated to induce shooting in Caesalpinia echinata Lam. (pau-brasil). A high exogenous supplementation of cytokinin increases the activity of enzyme cytokinin oxidase, which tends to disfavor the induction of shooting in the explant, thus cytokinin would cease to promote cell division (George, 2008).

For the variable number of leaves (Figure 2C), the analysis of variance presented statistical difference only for the isolated factors, with the regression indicating an ascendant quadratic model between the concentration of 2 and $4 \mu \mathrm{M}$ of BAP, occurring decrease when using higher concentrations. For NAA, the statistical analysis pointed to a decreasing linear model, with a higher number of leaves found in the absence of this regulator. For Erythrina velutina Willd., a higher average of 9.4 leaves was reached in culture medium supplemented with 17.76 $\mu \mathrm{M}$ of BAP combined with $1.34 \mu \mathrm{M}$ of NAA (Costa et al., 2010). According to Costa et al. (2010), the number of leaves in the multiplication phase is quite favorable, given that the gem is produced at the region located between the stem and the leaf, which can originate new shoots and, consequently, increase the multiplication rate.

The BAP cytokinin has been used to promote and proliferation of shoots and to induce adventitious gems because, in this class, the plant regulator was more effective in the multiplication of many woody species and still provide lower acquisition cost. Figure 3 shows the presence of multiple shoots of $B$. gardneriana formed from nodal segments exposed for 45 days at concentrations of 2.0 and $4.0 \mu \mathrm{M}$ of BAP.

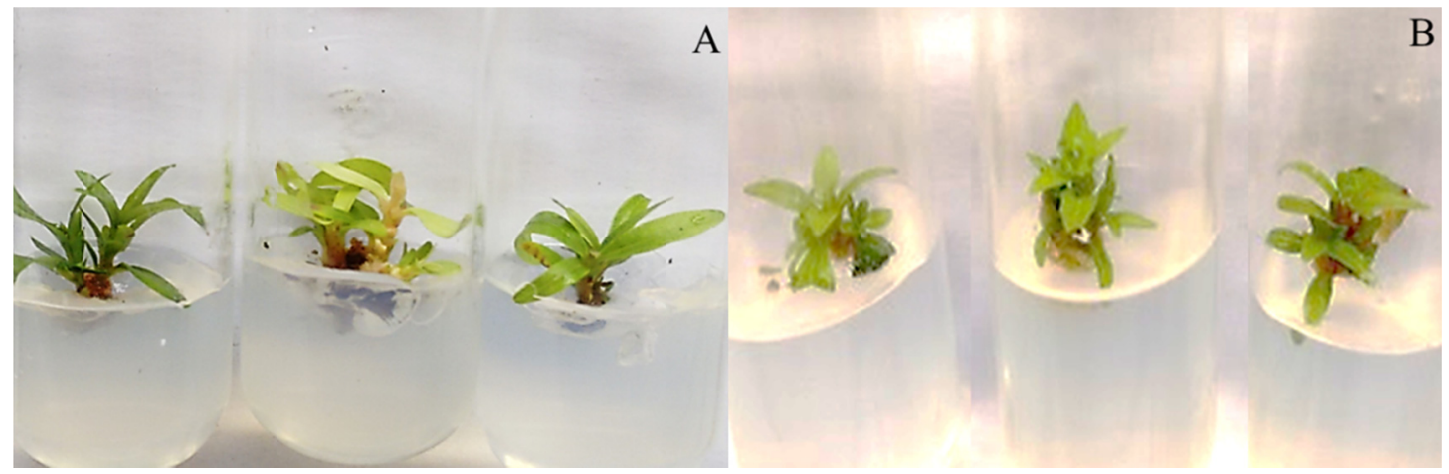

Figure 3. B. gardneriana shoots formed in vitro after 45 days in culture medium containing $2.0 \mu \mathrm{M}$ (A) and 4.0 $\mu \mathrm{M}(\mathrm{B})$ of BAP

As was observed in the study in question, the NAA auxin has not interfered in the results. When NAA is added to the culture medium, it tends to inhibit the normal growth of the shoot, the proliferation of shoots and the number of leaves. However, it is widely employed in association with BAP, given that the appropriate interaction between both can favor even more the quality of the micropropagated plants (Torres et al., 1998).

To rootings induction in shoots of murici there was no statistical difference for variable survival percentage of the seedlings when cultivated in culture medium supplemented with different concentrations of IBA, in the presence or absence of activated charcoal, presenting a general average of $98 \%$ of survival.

For variables number of roots ad length of the longest root, only the variation factor presence and absence of activated charcoal was significant, in which without the addition of activated charcoal, we verified the formation of root presenting an average of 1.0 root per shoot (Table 1). In the culture mediums with activated charcoal, 
regardless of the different concentrations of IBA testes, we observed no root development. These results confirm those found by Erig, Schuch, and Braga (2004) with sieve in vitro rooting (Pyrus communis L.), and by Schwalbert, Maldaner, Amaral, Aita, and Tarouco (2015) with Desmodium incanum DC., in which the presence of this component did not alter the rooting rate of this species. This fact can possibly be explained in function of the capacity of the activated charcoal to alter the $\mathrm{pH}$ of the culture medium, adsorb a portion of all elements that comprise the medium, causing nutritional deficiency, as well as making a lower amount of free auxin available for the shoots (Grattapaglia \& Machado, 1998), damaging the rooting of this species. For the test concentration of IBA, there was no statistical difference between treatments, presenting a general average of $36 \%$ of number of roots. However, we verified higher root vigor when the culture medium was supplemented with the highest concentration of IBA. However, for many plant species, the use of IBA was shown to be beneficial, such as with A. cearenses specie, presenting rooting rate of $92 \%$ in the presence of $10.0 \mu \mathrm{M}$ of IBA (Campos, Lima-Brito, Gutierrez, Santana, \& Souza, 2013). V. agnus-castus presented 90\% (Balaraju, Lima-Brito, Gutierrez, Santana, \& Souza, 2008) and Pistaceae vera L. presenting 84\% (Tilkat, Onay, Yıldırım, \& Ayaz, 2009) of rooting, both species in culture medium supplemented with $0.49 \mu \mathrm{M}$ and $9.84 \mu \mathrm{M}$ de IBA, respectively. The IBA is the synthetic auxin most commonly used for inducing rooting for presenting the property of promoting the formation of early roots. This regulator has been used to induce rooting of numerous plant species. According to Souza and Pereira (2007), the responses for induction and initiation of adventitious roots are regulated by the quantitative relation between the levels of auxin and cytokinin in the plant, where these endogenous contents vary according to the studied species.

Table 1. Number of roots in B. gardneriana sprouts in the presence and absence of activated charcoal

\begin{tabular}{lll}
\hline Treatments & No. of roots & Length of the longest root $(\mathrm{cm})$ \\
\hline Presence of activated charcoal & $0.0^{\mathrm{b}}$ & $0.0^{\mathrm{b}}$ \\
Absence of activated charcoal & $1.0^{\mathrm{a}}$ & $0.9^{\mathrm{a}}$ \\
\hline
\end{tabular}

Note. Means followed by the same letters do not differ statistically between each other at the level of $5 \%$ of probability by the Scott-Knott test.

\section{Conclusion}

Combinations of BAP with IAA, as well as with NAA, presented a negative effect on the in vitro multiplication of shoots of B. gardneriana. The use of BAP presents $100 \%$ efficiency of shoot induction from nodal segments. The concentration of 2.0 and $4.0 \mu \mathrm{M}$ of BAP was efficient for multiplication, given that, above these concentrations, the efficiency decreases. In vitro rooting occurred in all treatments evaluated, even in the absence of the IBA regulator, except in the presence of activated charcoal. New studies on in vitro multiplication are recommended in order to optimize shoot formation, and the use of IBA in more elevated concentrations, in order to optimize in vitro rooting protocol for the studied species.

\section{Acknowledgements}

We thank the Plant Tissue Culture Laboratory located in Experimental Unit Horto Florestal, Universidade Estadual de Feira de Santana (UEFS) for the technical support and the Coordenação de Aperfeiçoamento de Pessoal de Nível Superior (CAPES) for financial support.

\section{References}

Aragão, A. K. O., Aloufa, M. A. I., \& Costa, I. A. (2008). O efeito do bap (6-benzilaminopurina) sobre a indução de brotos em explantes de pau-brasil. Cerne, 17(3), 339-345. https://doi.org/10.1590/S0104-776020110 00300007

Balaraju, K., Agastian, P., Preetamraj, J. P., Arokiyaraj, S., \& Ignacimuthu, S. (2008). Micropropagation of Vitex agnus-castus, (Verbenaceae) - A valuable medicinal plant. In vitro Cellular and Developmental Biology-Plant, 44, 436-441. https://doi.org/10.1007/s11627-008-9155-9

Campos, V. C. A., Lima-Brito, A., Gutierrez, I. E. M., Santana, J. R. F., \& Souza, A. V. V. (2013). Micropropagação de umburana de cheiro. Ciência Rural, 43(4), 639-644. https://doi.org/10.1590/ S0103-84782013005000018

Costa, G. M., Nepomuceno, C. F., \& Santana, J. R. F. (2010). Propagação in vitro de Erythrina velutina. Ciência Rural, 40(5), 1090-1096. https://doi.org/10.1590/S0103-84782010005000084 
Donadio, L. C., Môro F. V., \& Servidone, A. A. (2002). Frutas brasileiras. Jaboticabal, SP: Novos talentos.

Erig, A. C., Schuch, M. W., \& Braga, E. J. (2004). Enraizamento in vitro de pereira (Pyrus communis L.) cv. Carrick. Ciência Rural, 34(1), 275-277. https://doi.org/10.1590/S0103-8478200400010004

Ferreira, D. F. (2011). Sisvar: A computer statistical analysis system. Ciência e Agrotecnologia, 35(6), 1039-1042. https://doi.org/10.1590/S1413-70542011000600001

Furtado, C. M., Carvalho, J. M. F. C., Castro, J. P., \& Silva, H. (2007). Comparação da frequência de regeneração in vitro do amendoim (Arachis hipogaea), utilizando diferentes citocininas. Revista de Biologia e Ciências da Terra, 7(1), 51-58.

George, E. F. (2008). Plant Tissue Culture Procedure-Background. In E. F. George, M. A. Hall, \& G. De Klerk (Eds.), Plant Propagation by Tissue Culture (pp. 1-28). The Netherlands: Springer, Dordrecht.

Grattapaglia, D., \& Machado, M. A. (1998). Microprapagação. In A. C. Torres, L. S. Caldas, \& J. A. Buso (Eds.), Cultura de Tecidos e Transformação Genética de Plantas (pp. 183-260). Brasília, DF: Embrapa-SPI \& Embrapa-CNPH.

Kang, B., Osburn, L., Kopsell, D., Tuskan, G. A., \& Cheng, Z. M. (2009). Micropropagation of Populus trichocarpa 'Nisqually-1': The genotype deriving the Populus reference genome. Plant Cell Tissue Organ Culture, 99, 251-257. https://doi.org/10.1007/s11240-009-9596-9

Martendal, C. O., Bernardino, M. M., Pereira, F. D., Silva, F. G., Menezes C. C. E., \& Santana, J. G. (2014). In vitro multiplication of nodal segments of "Murici" (Byrsonima cydoniifolia A. Juss.): The use of growth regulators and photoautotrophic stimulation. Journal of Agricultural Technology, 10(3), 665-678.

Murashige, T., \& Skoog, F. (1962). A revised medium for rapid growth and bioassays with tobacco tissue cultures. Physiologia Plantarum, 15(3), 473-497. https://doi.org/10.1111/j.1399-3054.1962.tb08052.x

Noleto, L. G., \& Silveira, C. E. S. (2004). Propagação in vitro de Copaifera langsdorffii. Revista Biotecnologia Ciência e Desenvolvimento, 33, 109-120.

Pereira, O. M., Navroski M. C., \& Reiniger, L. R. S. (2015). Multiplicação in vitro de ipê-amarelo (Handroanthus chrysotrichus). Nativa, 3(1), 59-63. https://doi.org/10.14583/2318-7670.v03n01a10

Sannomiya, M., Fonseca, V. B., Silva, M. A., Rocha, L. R. M., Santos, L. C., Hiruma-Lima, C. A., ... Vilegas, W. (2005). Flavonoids and antiulcerogenic activity from Byrsonima crassa leaves extracts. Journal of Ethnopharmacology, 97, 1-6. https://doi.org/10.1016/j.jep.2004.09.053

Schwalbert, R., Maldaner, J., Amaral, G. A., Aita, M. F., \& Tarouco, A. K. (2015). Multiplicação in vitro de Desmodium incanum em presença de carvão ativado. Enciclopédia Biosfera, 21, 1365-1373.

Seixas, E. N. C., Silva, M. A. P., Morais, A. C. A., \& Santos, M. A. F. (2011). Biologia reprodutiva e propriedades químico-farmacológicas de Byrsonima Rich. ex Kunth. (Malpighiaceae) no Nordeste, Brasil. Caderno de Cultura e Ciência, 10(2), 7-16. https://doi.org/10.14295/cad.cult.cienc.v10i2.399

Souza, A. V., \& Pereira, A. M. S. (2007). Enraizamento de plantas cultivadas in vitro. Revista Brasileira de Plantas Medicinais, 9(4), 103-117.

Tilkat, E., Onay, A., Yıldırım, H., \& Ayaz, E. (2009). Direct plant regeneration from mature leaf explants of pistachio, Pistacia vera L. Scientia Horticulturae, 121(3), 361-365. https://doi.org/10.1016/j.scienta.2009. 02.007

Torres, A. C., Caldas, L. S., \& Buso, J. A. (1998). Cultura de Tecidos e Transformação Genética de Plantas. Brasília, DF: EMBRAPA/CBAB.

\section{Copyrights}

Copyright for this article is retained by the author(s), with first publication rights granted to the journal.

This is an open-access article distributed under the terms and conditions of the Creative Commons Attribution license (http://creativecommons.org/licenses/by/4.0/). 